\title{
Editorial
}

\section{Democratizar el conocimiento es publicar en acceso abierto en revistas científicas}

\author{
Cleofé Genoveva Alvites-Huamaní ${ }^{1}$ \\ https://orcid.org/0000-0001-6328-6470 \\ Universidad Alas Peruanas, Perú
}

Democratizing knowledge is publishing in free access in scientific journals

\section{Cita Recomendada}

Alvites-Huamaní, C. (2020). Democratizar el conocimiento es publicar en acceso abierto en revistas científicas. Hamut'ay 7(1), 5-7.

http://dx.doi.org/10.21503/hamu.v7i1.1905

\section{INTRODUCCIÓN}

El realizar investigación conlleva a una serie de criterios y lineamientos para los investigadores, desde el diseño, ejecución y finalización, y la divulgación de los resultados y hallazgos encontrados a la comunidad académica y público interesado en la temática, siendo una prioridad en cada uno de los investigadores el presentar los aspectos relevantes hallados en todo el proceso de su investigación, lo cual se ha podido concebir mediante artículos científicos, pero con ciertas restricciones debido a que no todas las revistas permiten la lectura a texto completo de estas investigaciones o su tiraje impreso es limitado por ser solo impresa y en el caso de las revistas electrónicas ponen un tiempo de embargo a los artículos, lo cual por muchos años ha sido un obstáculo para muchos académicos interesados en el conocimiento de su especialidad y el poder conocer estudios similares que sean un referente para sus estudios. Pero se debe hacer un paréntesis al respecto, ya que en un mundo globa-

\section{INTRODUCTION}

Developing research carries a series of criteria and guidelines for researchers, from design, execution and conclusion, and the dissemination of the results and findings found to the academic community and public interested in the subject, being a priority for each one of the researchers presenting the relevant aspects found in the whole process of their research, which can be conceived through scientific papers, but with some restrictions due to not all journals allow the reading to complete text from these investigations or their printed run is limited for being just printed and in the case of electronic journals there is an embargo time for papers, which has been an obstacle for many academicians interested in knowledge from their specialty and to know similar studies as a reference for their studies. But there must be a parenthesis about this, as in a globalized world like ours, where information technology and communication have had a prevailing incidence having overstepped 
lizado como el nuestro, donde las tecnologías de la información y comunicación han tenido una incidencia preponderante al haber traspasado fronteras en todo ámbito, la producción científica no está exenta, por el contrario ha permitido dar paso a una nueva tendencia en el acceso abierto al conocimiento, solo con la finalidad de compartir y diseminar los resultados de sus estudios entre todos los miembros de la comunidad científica, (Herrmann-Lunecke \& Inzulza-Contardo, (2018 p.2).

\section{Acceso Abierto}

Para Herrmann-Lunecke \& Inzulza-Contardo, (2018) el acceso abierto es una publicación en formato digital en línea, gratuita, libre de restricciones de derechos de autor con libertad para circular y difundirse. Aguado, (2016) refiere que el acceso abierto es un movimiento que ha permitido abrir el conocimiento y la divulgación científica como alternativa que han impacto en los procesos de producción y comunicación de la ciencia, haciendo que estas estén disponibles en línea sin barreras económicas y sin requerir permisos u otro tipo de restricción (Luchilo, 2019). Además, publicar en medios de acceso abierto causa un efecto multiplicador sobre el impacto de los artículos publicados, ya que no se tiene restricciones y se pone al alcance de otros investigadores y de público en general interesado en conocer el avance de la ciencia (Mandía-Rubal, López-Ornelas \& Túñez-López, 2019; Aliaga, 2014). También está permitiendo el desarrollo de plataformas digitales y bases de datos en acceso abierto como el Open Journal Sistem (OJS), Directory Open Access Journal (DOAJ), entre otros (Aguado \& Vargas, 2016). Ha impulsado el garantizar a los lectores el tener literatura científica con acceso para descargar, copiar, distribuir, leer e imprimir de manera gratuita textos completos, donde lo más resaltante es que no pagan ni los autores ni los lectores (Bongiovani \& Miguel, 2019).

\section{Revistas científicas y el acceso abierto}

Las revistas científicas son uno de los medios que sirven como instrumento para que la ciencia presente los nuevos conocimientos, desarrollos o hallazgos encontrados en diversas áreas y especialidades que realizan los investigadores y académicos a borders in all areas, scientific production is not exempt, on the contrary has opened the way for a new trend in the open access to knowledge, with the only purpose of sharing and disseminating the results from their studies among the members of the scientific community, Herrmann-Lunecke $\&$ Inzulza-Contardo, (2018 p.2).

\section{Free Access}

For Herrmann-Lunecke \& Inzulza-Contardo, (2018) free access is a publication in digital format online, free, without copyright restrictions with the freedom to circulate and be disseminated. Aguado, (2016) refers free Access as an organization which has allowed knowledge and scientific release as an alternative that has affected processes of production and communication in science, making them available online without economical barriers and without requiring permission or another kind of limitation (Luchilo, 2019). Moreover, publishing in free access media is an expanded effect on the impact of the published papers, since there are no restraints and it is accessible to other researchers and general public who are interested in knowing the advance of science (Mandía-Rubal, López-Ornelas \& Túñez-López, 2019; Aliaga, 2014). In addition is allowed the development of digital platforms and data base in free access like Open Journal Sistem (OJS), Directory Open Access Journal (DOAJ) among others (Aguado \& Vargas, 2016). It has motivated to guarantee the readers having scientific literature with access to download, copy, distribute, read, print free of charge complete texts and the most remarkable is that neither authors nor readers pay (Bongiovani \& Miguel, 2019).

\section{Scientific journals and free access}

Scientific journals are one of the media which are used as instrument for science to present new knowledge, developments or findings found in several areas and specialties that conduct researchers and academicians worldwide, besides the contribution from internet and information technology and communication, due to have allowed an accelerated transformation in scientific dissemination, having changed from printed journals to electronic ones, (Sádaba, 2014), just as the main 
nivel mundial, junto a ello el aporte que ha brindado el Internet y las tecnologías de la información y comunicación, debido a que han permitido una transformación acelerada en la divulgación científica, habiendo pasado de revistas impresas a electrónicas (Sádaba, 2014), así como el soporte principal de comunicación a la comunidad científica de todo aquello nuevo que se está realizando o descubriendo en el mundo investigativo y académico en las diversas áreas y también constituyen una ventana abierta para el reconocimiento científico de los investigadores y sus instituciones aunado a ello el surgimiento del movimiento de acceso abierto ha permitido brindar un bagaje de información nueva y relevantes a la comunidad científica (Luchilo, 2019; D’Antonio, 2014). Además, el acceso abierto en revistas científicas ha dado paso a que los artículos están autorizados a ser reutilizados por tener accesibilidad a los contenidos (Labastida, 2019; Segado-Boj, Martín-Quevedo \& Prieto-Gutiérrez, 2018). El uso de las tecnologías de la información y comunicación ha impactado en la producción científica al permitir la creación de revistas electrónicas dejando de lado en muchos países revistas impresas y en algunos pocos casos el continuar en las dos versiones, siendo las revistas electrónicas las que están teniendo una tendencia mayor al acceso abierto, ya que para algunos investigadores este les aumenta el ser consultados y citados (Tárraga et al., 2013; Segado-Boj, Martín-Quevedo \& Prieto-Gutiérrez, 2018). Conscientes de este rol dentro la comunidad científica en divulgación de la ciencia, la revista Hamut'ay desde sus inicios ha sido y seguirá siendo una revista de acceso abierto y gratuita. support of communication to scientific community about every new development or discovering the investigative and academic world in diverse areas and also symbolizes an open window for scientific knowledge of researchers and their institutions joined to the emergence of the free access movement has allowed to provide a grounding of new and relevant knowledge for the scientific community (Luchilo, 2019; D’Antonio, 2014). Furthermore, free access in scientific journals has cleared the way to papers authorized to be reused for having access to the contents (Labastida, 2019; Segado-Boj, Martín-Quevedo \& Prieto-Gutiérrez, 2018). The usage of information technology and communication has affected scientific production allowing the creation of electronic journals putting aside in many countries the printed ones and in a few cases continuing both versions, being electronic journals which are having higher trend to free access, considering that for some researchers this one improves the fact of being consulted and cited (Tárraga et al., 2013; Segado-Boj, Martín-Quevedo \& Prieto-Gutiérrez, 2018). Aware of this role inside the scientific community in dissemination of science the journal Hamut'ay has been from the beginning and will be a free access journal and free of charge. 


\section{REFERENCIAS BibLIOGRÁFICAS}

Aguado, E. (2016). Diálogo científico y visibilidad de las revistas iberoamericanas certificadas: la experiencia de Redalyc. org. Congreso Nacional de Revistas científicas Comunidad Académica y Políticas Editoriales. Ramos, M. y González, D. (Eds.). Ediciones Universidad Autónoma de Yucatán. 31-41

Aguado, E. \& Vargas, E., (2016). Reapropiación del conocimiento y descolonización: el acceso abierto como proceso de acción política del sur. Rev. Colomb. Soc., 39(2), 69-88. https://doi.org/10.15446/rcs.v39n2.58966

Aliaga, F. (2014). Veinte años de publicación electrónica y de acceso abierto: La madurez de una pionera. RELIEVE, 20 (1).https://doi.org/10.7203/relieve.20.1.3856

Bongiovani, P. C. \& Miguel, S. E. (2019). ¿Cuán abierta es la producción científica de los investigadores argentinos de Ciencias Sociales? Palabra Clave (La Plata), 9(1). https://doi.org/10.24215/18539912e080

D'Antonio, S. (2014). Algunas reflexiones en torno al acceso abierto, revistas científicas y el campo de publicación académica. Argumentos de Razón Técnica 17, 173-187.

Herrmann-Lunecke, M. \& Inzulza-Contardo, J. (2018). Desafíos del acceso abierto de las revistas científicas de urbanismo, arquitectura, diseño y arte en Chile. Revista Cubana de Información en Ciencias de la Salud, 29 (2), 1-11.

Labastida, I. (2019). Analizando el estado del acceso abierto en una universidad. Revista de Unidades de Información, 15.

Luchilo, L. (2019). Revistas científicas: oligopolio y acceso abierto. Revista CTS, 40 (14), 41-79.

Mandía-Rubal, S., López-Ornelas, M. \& Túnez-López, J. (2019). Posicionamiento de las revistas en acceso abierto de Comunicación indizadas en Scimago Jurnal Rank (20072017). International Journal of Information Systems and Software Engineering for Big Companies (IJISEBC), 6(1), 21-33.

Sádaba, I. (2014). El acceso abierto en ciencias sociales: notas sociológicas sobre publicaciones, comunidades y campos. Argumentos de Razón Técnica, 17, 93-113.

Segado-Boj, F., Martín-Quevedo, J. \& Prieto-Gutiérrez, J. (2018). Percepción de las revistas científicas españolas hacia el acceso abierto, open peer review y altmetrics. Ibersid. 12 (1), 27-32.

Tárraga, R., Colomer, C., Fernández, I. \& Pastor, G. (2013). Análisis de la implantación de la política de publicación en acceso abierto en universidades españolas. Revista de investigación 3Ciencias, 1-12. 